\title{
A Systematic Review on the Deviant Workplace Behavior
}

\author{
Mohd Nazri Baharom, Mohd Dino Khairi Bin Sharfuddin and Javed Iqbal*
}

Ghazali Shafie Graduate School of Government, University Utara Malaysia, Kedah, Malaysia

\begin{abstract}
The purpose of this paper is to highlight the concept deviant workplace behavior through review of previous studies on deviance workplace behavior area and understand the dynamics of deviant workplace behavior. The first, the researcher discuss the need for research in deviance workplace behavior of employees especially to understand the impact of various factors on deviant workplace behavior. Secondly, the research carried out with the review of previous literature from the area of deviance workplace behavior and presents the summary on review of the literature relevant antecedents of deviant workplace behavior and prevalence cost of DWB. The third, the current study is totally based on the secondary source of data based on various journal referred and collected from various websites. Finally, the study presents its implications, the future directions and its limitation and conclusion of the study with respect to deviant workplace behavior in public organizations.
\end{abstract}

Keywords: Deviant workplace behavior; Individual factors; Organizational factors; Demographic factors; Transformational leadership

\section{Introduction}

In current era the study of the behavior of individual at workplace has been become imperative due to globalization, industrialization and technological advancement [1]. Deviant workplace behavior (DWB) is one of the most vital research area that influencing the behavior of employees at workplace [2] and effecting the health of organization [3]. Deviance workplace behavior (DWB) is a vital concern for research due to its evolving [4] and growing level and possible outcome an influence [5]. Deviant workplace behavior (DWB) in not a fresh knowledge to discuss in corporate world [6] but resources which create deviance workplace behavior are still guiding new dimension to examine with the passage of time and circumstances. The literature review of various scholars has defined deviance workplace behavior [2] and clarify the outcomes of deviant workplace behaviors [7]. But studies regarding workplace deviance behaviors are still need be considered [3]. Destructive workplace deviant behaviors are one of the most important research topics affecting well-being of organizational norms and performance [3]. Deviant workplace behavior is considered a key problem for every organization [8]. Therefore, the understanding of these workplace behavior and work-related attitudes have become a significant research area [3] and emerging phenomenon [9]. Deviant workplace behavior, either internal or organizational, mostly occurred among the employees at workplace [9]. Deviant workplace behavior (DWB) has been studied under different terms such as retaliation and dysfunctional behavior, organizational misbehavior [10] and counterproductive workplace behavior [5]. In the words of Robinson and Greenberg [11] there is no common definition regarding workplace deviance that is generally agreed upon" due to initial stage of research area and cited the definition of two eminent scholars who have elaborate this construct of deviant workplace behavior (DWB), operationalized it and key dimension as well as recognized its boundaries [6]. Eminent research scholars Robinson and Bennett [12] defined deviance workplace behavior (DWB) as "a voluntary behavior engaged by employee that is contrary to the significant organizational norms and it is considered as a threat to the well-being of an organization and/ or its members". Earlier researchers have given different expressions to the term deviance workplace behavior such as counterproductive workplace behavior [13] antisocial behavior organizational misbehavior, workplace sabotage [14], worker resistance, dysfunctional behaviour [15] and non-complaint behavior (Puffer) among others, "Bad Behavior" in Organizations [15]. According to Greenberg, "anti- social behavior" that is defined as "any behavior that brings harm or is intended to bring harm to the organization and its employees or its stakeholders" In the words of Robinson and Morrison, [16] "workplace deviance" that is defined as "voluntary behavior of organizational members that violates significant organizational norms and in so doing, threatens the well-being of the organization and/its members". Deviant workplace behaviors (DWB) of employees are directly harmful to the organization or to other employees in the organization [17] that can range from relatively minor to very serious [18]. Griffin and Lopez [15] noted that all individuals who enter to working organizations have the potential to exhibit this destructive behavior that categories, minor and major deviance. The first, minor, production deviance [12], working slow intentionally, avails excessive breaks [8], gossiping on non-work topics with coworkers during official working hours, late arrival at workplace and leave office early, day dreaming while on job [8], and involved in cyber loafing [19]. The second major, production deviance as theft from organization, do slow work to obtain unnecessary due overtime, without receiving permission to use photocopy machines for personnel purpose, as well as taking office supplies or equipment at home $[20,21]$. On the other hand, interpersonal deviance, has also two categories, minor and major, the first, political deviance is making fun, deal rudely and blaming to coworkers for mistakes did on job, disobeying supervisor's directions and instructions the second, personal aggression, (major) such as cursing, humiliating, bullying or stalking and saying hurtful things to coworkers and assaulting with injury to coworkers too [22].

\section{Objectives of the Study}

The main aim of this systematic review is to identify and describe the antecedents that push the employees to indulge in deviant workplace behavior. The second objective of this systemic review is to understand,

*Corresponding author: Javed Iqbal, Ghazali Shafie Graduate School of Government, University Utara Malaysia, Kedah, Malaysia, Tel: +60 4-928 4000; E-mail: javedlatif2016@gmail.com

Received November 04, 2017; Accepted November 29, 2017; Published December 10, 2017

Citation: Baharom MN, Sharfuddin MDKB, Iqbal J (2017) A Systematic Review on the Deviant Workplace Behavior. Review Pub Administration Manag 5: 231 doi:10.4172/2315-7844.1000231

Copyright: (c) 2017 Baharom MN, et al. This is an open-access article distributed under the terms of the Creative Commons Attribution License, which permits unrestricted use, distribution, and reproduction in any medium, provided the original author and source are credited. 
define and explain the dynamics of DWB and factors contributed DWB. Third objective of this study is, to grasp the knowledge of the area under research related to mediating and moderating effect between deviant workplace behavior and various other factors. Fourthly, to understands the various theories supporting to theoretical prospective of the deviant workplace behavior. Fifthly, the study will also broaden the understanding of the previous research of DWB and allied area of study. And, finally, the present study on systemic review will create and established a Gap for further research in focus area for future researchers.

\section{Research Methodology}

Electronic searches were performed on data bases containing published studies on employee's behavior i.e. deviant workplace behavior, counterproductive workplace behavior and unethical behavior etc. searches were limited to scientific papers/articles, available in full text and published in English during Jan 2000 to Oct 2017. The query was deviance workplace behavior, or deviant workplace behavior or counterproductive workplace behavior or misconduct at workplace or misbehavior or unethical behavior or violence at work. In addition, the reviews of literature have also been undertaken on the basis of five to six factors. They are individual factors i.e. Big five personality traits and dark triad personality traits and organizational factors i.e. organizational injustice, abusive supervision and transformational leadership and deviant workplace behavior or counterproductive workplace behavior. Empirical, original and review articles/papers were selected for current study and focusing on deviance workplace behavior. For the selection of articles/papers on DWB, four phases adopted. Firstly, identification, secondly screening based on the title and abstract reading. Thirdly, eligibility evaluation through full text readings and fourthly, inclusion of article in present paper on the base of empirical study or review on the focus area of DWB. Lastly, the study focuses on articles/papers found through Google and Google scholar search engine on the DWB and allied area.

\section{Literature Review}

\section{Significance of the study}

The present study will contribute to the academic literature on counterproductive workplace or deviance workplace behavior and enhance the understanding the of deviance behavior of employees among the researcher, practitioners and manager. The study will also explain reasons for occurrence of deviance at workplace in public organizations. Another important fact emerging from this literature "systemic review: is to establish the relationship between DWB and other moderating and mediating factors. The given below Table 1 explore the prevalence and cost of deviance at workplace [23-38].

The summary reveals the severity of prevalence and cost of deviance workplace behavior.

The given Table 2 shows the summary of all the studies that have been since long from 2000 so for on deviance workplace behavior of employees [39-112].

\section{Discussion}

\section{Future directions and limitations}

Although, the present study has provided support for a number of the studies hypothesized on relationship among the exogenous, endogenous and intervening variables related to deviant workplace behavior. This study generally focuses on systemic review of individual factors i.e. personality traits and organizational factors i.e. organizational injustice and abusive supervision and transformational

\begin{tabular}{|c|c|}
\hline Source & Cost of DWB \\
\hline \multirow{3}{*}{ Alam } & $\begin{array}{l}\text { According to world economics forums estimates that } \\
\text { "corruption is equal to } 5 \% \text { for global GDP with over US } \\
\$ 1 \text { trillion paid in bribes each year }\end{array}$ \\
\hline & $\begin{array}{l}\text { Estimated between US } \$ 15-\$ 20 \text { billion of ODA is lost } \\
\text { due to corruption in Africa region alone }\end{array}$ \\
\hline & $\begin{array}{l}\text { In Pakistan one government officers is accused of } \\
\text { corruption in the rupees } 42 \text { billion equal to US } \$ 420 \\
\text { million (Express tribune 2014) }\end{array}$ \\
\hline $\begin{array}{c}\text { Alias, Rasdi, Ismail } \\
\text { and Samah [23], } \\
\text { Bennett and Galperin } \\
{[12,24]}\end{array}$ & $71 \%$ responded reported to workplace incivility \\
\hline $\begin{array}{l}\text { Appellbaum, Semerjian } \\
\text { and Mohan [25] }\end{array}$ & $\begin{array}{l}\text { Approximately } 1.7 \text { million Americans and } 11 \% \text { British } \\
\text { employees experiences different type of bullying such } \\
\text { as physically assault, on-verbal, threating, intimidating, } \\
\text { humiliating, sabotage, interference with the production } \\
\text { and exploitation at work place }\end{array}$ \\
\hline \multirow{2}{*}{$\begin{array}{c}\text { Aliase cited Price } \\
\text { Water House Coopers }\end{array}$} & $\begin{array}{l}51 \% \text { of employees had fallen victim to fraud in 2003- } \\
2005 \text { at workplace in Thai companies }\end{array}$ \\
\hline & $\begin{array}{l}\text { Frauds have caused a decline in employee morale in } \\
60 \% \text { of Thai and Asia-pacific companies }\end{array}$ \\
\hline $\begin{array}{l}\text { Appelbaum, Semerjian } \\
\text { and Mohan [25] }\end{array}$ & $\begin{array}{l}\text { Approximately } 1.7 \text { million Americans and } 11 \text { percent of } \\
\text { British employees experienced Deviance of bullying at } \\
\text { workplace }\end{array}$ \\
\hline Bensimon & $\begin{array}{l}\text { Approximately } 1.5 \text { million Americans become works } \\
\text { place victims of violence and organization, suffering a } \\
\text { cost } \$ 4.2 \text { billion annually }\end{array}$ \\
\hline \multirow{2}{*}{$\begin{array}{l}\text { Bolton and Grawitch } \\
\text { [26] }\end{array}$} & $\begin{array}{c}\text { Deviance at workplace is quite prevalent and costly to } \\
\text { organization and }\end{array}$ \\
\hline & $\begin{array}{c}33.75 \text { percent of all employees involved in some kind of } \\
\text { deviance behavior }\end{array}$ \\
\hline \multirow{2}{*}{ Buss [27] } & Loss of $\$ 200$ billion for employees' theft \\
\hline & $\$ 400$ billion for different type of fraud \\
\hline Case & $\begin{array}{l}\$ 50 \text { billion loss estimated annually and is responsible } \\
\text { for almost a } 20 \% \text { of failure of business due to counter } \\
\text { workplace behavior such as employee's theft and fraud }\end{array}$ \\
\hline Chen & $\begin{array}{c}\text { U\$ } 2.9 \text { trillion estimated annual losses as a result of } \\
\text { fraudulent activity }\end{array}$ \\
\hline $\begin{array}{l}\text { Chappell and Martino } \\
\text { [28] }\end{array}$ & $\begin{array}{c}\text { In Australia, employers incurred estimated costs } \\
\text { between } 6 \text { and } 13 \text { billion Australian dollars annually on } \\
\text { DWB acts i.e. theft and bullying }\end{array}$ \\
\hline Coffin [29] & $\begin{array}{l}\text { Estimated } 33 \% \text { to } 75 \% \text { of all employees engaged in } \\
\text { deviant behavior such as abuse against others/bullying, } \\
\text { production deviance, sabotage, theft, withdrawal etc. }\end{array}$ \\
\hline $\begin{array}{c}\text { Cortina, Magley, } \\
\text { Williams and Langhout } \\
{[30]}\end{array}$ & $\begin{array}{c}\text { During the previous } 5 \text { years } 71 \% \text { of the respondents } \\
\text { reported incivility in public service organizations in the } \\
\text { United States, } 6 \% \text { of them reported to experience that } \\
\text { negative behaviors }\end{array}$ \\
\hline $\begin{array}{l}\text { Einarsen, Hoel, Zapf } \\
\text { and Cooper }\end{array}$ & $\begin{array}{l}\text { In most countries there seems to be a tendency for } \\
\text { workplace deviance to occur more often in public sector }\end{array}$ \\
\hline Goh [31] & $\begin{array}{c}\text { Estimated } \$ 300 \text { billion total loss annually sustained } \\
\text { due to employees absenteeism, theft and diminish } \\
\text { productivity in United States }\end{array}$ \\
\hline Harper [32] & $\begin{array}{l}1 / 3 \text { to } 3 / 4 \text { of all employees engaged in some type of } \\
\text { fraud, sabotage or Vandalism in their workplace }\end{array}$ \\
\hline Hollinger and Adam & $\begin{array}{l}\text { Reported in } 2010 \text {, US retailers endorsed nearly } 45 \% \text { of } \\
\text { their inventory shortage which representing prevalence } \\
\text { and burden of approximately } \$ 15.9 \text { billion on retail } \\
\text { business due to employee's theft }\end{array}$ \\
\hline \multirow{3}{*}{ Jacobson } & $\begin{array}{l}\text { The united states suffer estimated } \$ 4.2 \text { billion from } \\
\text { workplace violence }\end{array}$ \\
\hline & $\$ 200$ billion annually due to employees theft \\
\hline & $\begin{array}{c}\text { Suffering } \$ 5.3 \text { million due to the misuse of internet } \\
\text { during working hours }\end{array}$ \\
\hline KPMG Francis & $\begin{array}{l}\text { Approximately } \$ 2.1 \text { million for each incident at work } \\
\text { place reported in Australia }\end{array}$ \\
\hline
\end{tabular}




\begin{tabular}{|c|c|}
\hline $\begin{array}{l}\text { Lehman, Holcon and } \\
\text { Simpson }\end{array}$ & $\begin{array}{l}\text { Estimated } 25 \% \text { of employees admitted having } \\
\text { knowledge of drug use among their co-workers at } \\
\text { workplace }\end{array}$ \\
\hline Lim and Chen [33] & $\begin{array}{l}\text { In United Kingdom employees, spent about } 40 \% \text { of their } \\
\text { time cyber loafing (Amble,2004) and incurred cost UK } \\
\text { businesses about } £ 154 \text { million a year (Hallett 2002) }\end{array}$ \\
\hline \multirow{4}{*}{ Malisetley and Kumari } & $\begin{array}{l}\text { In India 1.7 Million Indian's experiences rough } \\
\text { exploitation at workplace yearly }\end{array}$ \\
\hline & $\begin{array}{c}12 \% \text { of employees in IT Sector reported having been } \\
\text { tormented at workplace in the earlier six months of a } \\
\text { year }\end{array}$ \\
\hline & $\begin{array}{l}\text { Estimated } \$ 15.1 \text { billion lose every year in social } \\
\text { rebuilding by IT commercial enterprises }\end{array}$ \\
\hline & $\begin{array}{l}\text { In } 2014 \text {, misrepresentation conferred by hierarchical } \\
\text { individual cost of normal } \$ 2.1 \text { million for every extortion } \\
\text { occurrence an association encounters }\end{array}$ \\
\hline McGurn & $\begin{array}{l}75 \text { percent of employees have theft from their respective } \\
\text { organization }\end{array}$ \\
\hline $\begin{array}{l}\text { Moorthy, Seetaram, } \\
\text { Somassunderam and } \\
\text { Goplan }\end{array}$ & $\begin{array}{l}\text { Organization lost estimated } \$ 20 \text { to } \$ 40 \text { billion per year } \\
\text { due to stealing/theft and shoplifting by employees }\end{array}$ \\
\hline Nguyen [34] & $\begin{array}{c}\text { In Canada, a study by the Conference Board of Canada } \\
\text { reported that economy lost } \$ 16.6 \text { billion in } 2012 \text { due to } \\
\text { workplace deviance absenteeism }\end{array}$ \\
\hline $\begin{array}{l}\text { Penney and Spector } \\
{[17]}\end{array}$ & $\begin{array}{c}\text { Businesses pay more than } \$ 150 \text { billion annually for } \\
\text { managing occupational stress of absenteeism of } \\
\text { employees }\end{array}$ \\
\hline Pizzino & $\begin{array}{c}\text { Surveys of public-sector employees of Canada and } \\
\text { the U.S.A., } 69 \% \text { of employees responded that they } \\
\text { had experienced some form of verbal aggression at } \\
\text { workplace }\end{array}$ \\
\hline \multirow{2}{*}{$\begin{array}{l}\text { Robinson and O. L. } \\
\text { Kelly Z [35] }\end{array}$} & $\$ 200$ billion due to employee's theft \\
\hline & $\$ 400$ billion for various type of fraud act \\
\hline $\begin{array}{l}\text { Robinson and } \\
\text { Greenberg [11] } \\
\text { Bensimon [36] }\end{array}$ & $\begin{array}{l}\text { Organizations sustained estimated cost } \$ 4.2 \text { billion } \\
\text { annually due to workplace violence }\end{array}$ \\
\hline Taylor [37] & $\begin{array}{l}\text { In U.K., estimated } \$ 600 \text { million per year loss of } \\
\text { productivity due to web surfing at workplace }\end{array}$ \\
\hline Verton [38] & $\begin{array}{c}33 \% \text { to } 40 \% \text { decline in productive due to surfing in } \\
\text { activities of virtual space }\end{array}$ \\
\hline
\end{tabular}

Table 1: Summary of review of prevalence and cost of deviance workplace behavior. leadership. However, the outcome of systemic review of various studies on DWB have to be interpreted under consideration of the some study' limitations: The first, this study assumes and adopts review of a crosssectional research design, majority of the studies based on adopted self-administrator questionnaire for collection of data and convenience sampling which does not allow casual inferences to be made from the targeted population. Therefore, a longitudinal research design in future needs to be considered to measure the theoretical constructs at different points in time to confirm and generalize the findings of the present study. Secondly, in the present study, it is pertinent to mention that the deviant workplace behavior reported was subjective. The outcome of the present research demonstrates that subjective data is valid and reliable for assessing deviant workplace behavior. Therefore, in future the outcome of the present research may be replicated by using objective measures of deviant workplace behavior. Thirdly, in previous studies deviant workplace behavior has been given various name i.e. counterproductive behavior (CWB), unethical workplace behavior and misbehavior etc. therefore, there are possible chances of missing of some publication/papers or article on DWB and that is not cover completely exhaustive of area of the study. Fourthly, the search strategy and quality of studies' evaluation criteria would have been influenced by the results obtained in the adequate and eligible studies on secondary source of data. Fifthly, the outcome of present study offers quite limited generalizability because it focused mainly on five to six factors. Therefore, in future it is essential, in order to generalize the finding to include other relevant factors as antecedents and dimensions of DWB. Sixthly, the present systemic review containing the information related to dimension of DWD, moderating and mediating variable and supporting theories but not included the outcome of the empirical study, therefore, in the researcher should also in include the outcome/result of each empirical study in system review of literature. Finally, the outcome of this systemic review are not intended to be a final aim/goal in DWB understanding but as a stage for moving towards further research on the area of DWB. It is pertinent to mention that DWB cannot be eradicated however, it can be control or minimize with suitable measures being to be taken.

\begin{tabular}{|c|c|c|c|}
\hline Source of article & Study constructs and antecedents & Moderator/Mediator & Theoretical framework \\
\hline Adejoh and Adejoh [39] & Empirical study on organizational and individual destructive deviance & NA & NA \\
\hline $\begin{array}{l}\text { Agboola and Salawu } \\
{[40]}\end{array}$ & Case study on organizational and individual destructive deviance & NA & Field Theory \\
\hline Ahmad and Omer [41] & Literature review on organizational and individual destructive deviance & Work family conflict & $\begin{array}{c}\text { Conservation of resource theory and } \\
\text { Reactance theory }\end{array}$ \\
\hline $\begin{array}{l}\text { Ahmad, Kiyani and } \\
\text { Hashmi [42] }\end{array}$ & $\begin{array}{c}\text { Empirical study on workplace deviance; Organizational Cynicism, } \\
\text { organizational injustice }\end{array}$ & Work alienation & Breach of Psychological Contract \\
\hline $\begin{array}{l}\text { Abdul and Nasurdin [43] } \\
\quad \text { Aksu [44] }\end{array}$ & $\begin{array}{l}\text { Empirical study on organizational and individual destructive deviance } \\
\text { Empirical study on organizational deviance and multi-factor leadership }\end{array}$ & $\begin{array}{l}\text { Trust in organization } \\
\text { (Mediator) and Locus of } \\
\text { control (Moderator) NA }\end{array}$ & $\begin{array}{c}\text { Social information processing theory, } \\
\text { Social exchange theory and equity } \\
\text { theory } \\
\text { Theory of multifactor leadership }\end{array}$ \\
\hline $\begin{array}{l}\text { Alias, Rasdi, Said and } \\
\text { Samah }[45,23]\end{array}$ & Literature review on organizational and individual destructive deviance & Job satisfaction (Mediator) & $\begin{array}{l}\text { Social Exchange theory and General } \\
\text { Strain theory }\end{array}$ \\
\hline $\begin{array}{l}\text { Alias, Rasdi and Said } \\
{[45]}\end{array}$ & $\begin{array}{c}\text { Empirical study on organizational and individual destructive deviance: } \\
\text { individual, situational factors. }\end{array}$ & NA & NA \\
\hline $\begin{array}{l}\text { Ambrose, Schminke } \\
\text { and Mayer [46] }\end{array}$ & $\begin{array}{l}\text { Empirical study on organizational and individual destructive deviance: } \\
\text { Interactional justice, Group structure. }\end{array}$ & $\begin{array}{l}\text { Justice climate (Mediator) } \\
\text { and Work group } \\
\text { structure(Moderator) }\end{array}$ & $\begin{array}{l}\text { Social Learning theory, Structural } \\
\text { Contingency theory, Justice theory } \\
\text { and Uncertainty management theory }\end{array}$ \\
\hline $\begin{array}{l}\text { Appelbaum, Deguire } \\
\text { and Lay [1] }\end{array}$ & $\begin{array}{c}\text { Literature Review on both positive and negative deviant Workplace } \\
\text { behaviors; Ethical climate }\end{array}$ & NA & Social Learning theory \\
\hline Appelaum and Shapiro & $\begin{array}{c}\text { Literature Review on both positive and negative deviant Workplace } \\
\text { behaviors; Leadership, justice, satisfaction, commitment, bonding and } \\
\text { normlessness }\end{array}$ & NA & $\begin{array}{l}\text { Social Learning theory, Social } \\
\text { Bonding theory, and Equity theory }\end{array}$ \\
\hline $\begin{array}{l}\text { Appelbaum,laconi and } \\
\text { Matousek [2] }\end{array}$ & $\begin{array}{l}\text { Literature Review on organizational and individual destructive deviance; } \\
\text { deviant role models, operational environment, individual personality } \\
\text {,justice and psychological empowerment }\end{array}$ & NA & $\begin{array}{l}\text { Social Learning Theory, Social } \\
\text { Bonding theory, Equity theory and } \\
\text { Cognitive Social theory }\end{array}$ \\
\hline
\end{tabular}


Citation: Baharom MN, Sharfuddin MDKB, Iqbal J (2017) A Systematic Review on the Deviant Workplace Behavior. Review Pub Administration Manag 5: 231. doi:10.4172/2315-7844.1000231

Page 4 of 8

\begin{tabular}{|c|c|c|c|}
\hline $\begin{array}{c}\text { Bagchi and } \\
\text { Bandyopadhyay [47] }\end{array}$ & Model testing on workplace deviance: Recession & NA & Becker's framework \\
\hline $\begin{array}{l}\text { Bahri, Langrudi and } \\
\text { Hosseinian [48] }\end{array}$ & $\begin{array}{c}\text { Empirical study on workplace deviance: Organizational justice, } \\
\text { Interpersonal conflict and job satisfaction }\end{array}$ & NA & NA \\
\hline $\begin{array}{l}\text { Bodankin and Tziner } \\
{[49]}\end{array}$ & Empirical study on constructive and destructive deviance behavior & NA & Social Cognitive theory \\
\hline $\begin{array}{l}\text { Bolin and Heartherly } \\
{[50]}\end{array}$ & $\begin{array}{c}\text { Empirical study on workplace deviance: Theft approval, Company } \\
\text { contempt, intent to quit and dissatisfaction }\end{array}$ & NA & NA \\
\hline $\begin{array}{l}\text { Bolton and Grawitch, } \\
{[26]}\end{array}$ & $\begin{array}{c}\text { Literature review on workplace deviance: Recommendation for } \\
\text { practitioners to address DWB }\end{array}$ & NA & NA \\
\hline $\begin{array}{c}\text { Bowling and } \\
\text { Eschlemaman [51] }\end{array}$ & Empirical study on workplace deviance: Work stressor & $\begin{array}{l}\text { Employee personality Ethical } \\
\text { climate (Moderator) }\end{array}$ & $\begin{array}{l}\text { Transactional theory of stress and } \\
\text { coping }\end{array}$ \\
\hline $\begin{array}{l}\text { Chen, Chen, and Liu, } \\
\text { [52] }\end{array}$ & Empirical study on workplace deviance: Negative affectivity & NA & NA \\
\hline $\begin{array}{l}\text { Chen, Fahb and Jina } \\
{[53]}\end{array}$ & Empirical study on workplace deviance: perceived organizational support & NA & NA \\
\hline $\begin{array}{l}\text { Chirasha and Mahappa } \\
{[54]}\end{array}$ & $\begin{array}{c}\text { Case study on deviant behavior in workplace: Organizational climate, } \\
\text { Organizational justice, Perceived organizational support, Trust, Work } \\
\text { stress and power lessens }\end{array}$ & NA & NA \\
\hline Chullen et al. [55] & $\begin{array}{l}\text { Empirical study on deviant behavior: Supportive leadership: leader } \\
\text { member exchange preserved organizational supports. Job design: } \\
\text { Intrinsic motivation and depersonalization }\end{array}$ & NA & $\begin{array}{l}\text { Leader Member Exchange } \\
\text { theory, Social Exchange theory, } \\
\text { Organization Support theory, } \\
\text { Self-determination theory and } \\
\text { Conservation of Resource theory }\end{array}$ \\
\hline Chung and Moon [56] & $\begin{array}{l}\text { Empirical study on constructive deviance behavior: Psychological } \\
\text { ownership }\end{array}$ & $\begin{array}{l}\text { Collectivistic orientation } \\
\text { (Moderator) }\end{array}$ & $\begin{array}{l}\text { Regularity focus theory. Social } \\
\text { identity theory and Stewardship } \\
\text { theory }\end{array}$ \\
\hline Christian and Ellis & $\begin{array}{c}\text { Empirical study on workplace deviance; Moral disengagement and } \\
\text { turnover intension }\end{array}$ & - & NA \\
\hline Colbert et al. [57] & $\begin{array}{l}\text { Empirical study on workplace deviance; personality and work situations } \\
\text { (perception of developmental environment) }\end{array}$ & $\begin{array}{l}\text { Conscientiousness, emotional } \\
\text { stability }\end{array}$ & $\begin{array}{l}\text { Social Exchange theory, Norm } \\
\text { of reciprocity and organizational } \\
\text { support theory }\end{array}$ \\
\hline Dagher and Junaid [58] & $\begin{array}{l}\text { Empirical study on constructive deviance behavior: Employs engagement } \\
\text { vigor, dedication and absorption }\end{array}$ & NA & NA \\
\hline $\begin{array}{l}\text { De Lara, Tacoronte and } \\
\text { Ting-Ding [59] }\end{array}$ & Empirical study on deviance behavior: Procedural justice & Perceived normative conflict & Equity theory \\
\hline $\begin{array}{l}\text { Diefndorff and Mehta } \\
{[60]}\end{array}$ & $\begin{array}{l}\text { Empirical study on workplace deviance behavior: Avoidance motivation, } \\
\text { personal mastery, competitive excellence, general approach motivation }\end{array}$ & - & Achievement motivation theory \\
\hline Demir [61] & $\begin{array}{c}\text { Empirical study on deviance behavior: Organizational justice, } \\
\text { Organizational trust, affective commitment, continues commitment, } \\
\text { nutritive commitment }\end{array}$ & NA & NA \\
\hline $\begin{array}{l}\text { Fagbohungbe,Akinbode } \\
\text { and Ayodeji [62] }\end{array}$ & $\begin{array}{l}\text { Empirical study on workplace deviance: Employees organizational } \\
\text { reaction }\end{array}$ & NA & $\begin{array}{c}\text { Affective Event Theory and Agency } \\
\text { Theory }\end{array}$ \\
\hline $\begin{array}{l}\text { Farasat and Ziaaddini } \\
{[63]}\end{array}$ & $\begin{array}{c}\text { Review on deviance behavior: Farness of treatment, Supervisor support, } \\
\text { organizational rewards and job condition }\end{array}$ & NA & Social exchange theory \\
\hline $\begin{array}{l}\text { Fatima, Atif, Saqib and } \\
\text { Haider [64] }\end{array}$ & $\begin{array}{c}\text { Empirical study on workplace deviance; impact of organizational injustice } \\
\text { on job satisfaction and, to impact of job satisfaction on Deviance } \\
\text { workplace behaviors. }\end{array}$ & $\begin{array}{l}\text { Job satisfaction } \\
\quad \text { (Mediator) }\end{array}$ & NA \\
\hline Farhadi et al. [65] & Empirical study on Deviant workplace behavior: Demographic Factors & NA & NA \\
\hline Fida et al. [66] & Empirical study on Counterproductive behavior; Moral disengagement & NA & NA \\
\hline $\begin{array}{l}\text { Ferris, Brown, Heller, } \\
\text { [67] }\end{array}$ & Empirical study on organizational deviance: Organizational support & $\begin{array}{l}\text { Organization based self- } \\
\text { esteem (Mediator) }\end{array}$ & Belongingness theory \\
\hline Ferris, Brown [67] & $\begin{array}{l}\text { Empirical study on deviance behavior: Level (high and low) and type } \\
\text { (contingent/ non-contingent) of self-steam }\end{array}$ & $\begin{array}{l}\text { Contingent self-esteem } \\
\text { (Moderator) }\end{array}$ & $\begin{array}{l}\text { Self-Consistency/ } \\
\text { Behavioral plasticity theory }\end{array}$ \\
\hline $\begin{array}{l}\text { Ferris, Spense, Brown } \\
\quad \text { and Helle [68] }\end{array}$ & $\begin{array}{l}\text { Empirical study on workplace deviance: Within personal relation of } \\
\text { interpersonal justice }\end{array}$ & Self-esteem (Moderator) & $\begin{array}{l}\text { Behavior plasticity theory, } \\
\text { conservation of resources theory }\end{array}$ \\
\hline Flaherty and Mass [69] & $\begin{array}{l}\text { Empirical study on workplace deviance behavior; personality. workplace } \\
\text { injustice and team context }\end{array}$ & NA & $\begin{array}{l}\text { Social exchange theory and Equity } \\
\text { theory }\end{array}$ \\
\hline $\begin{array}{l}\text { Galperine and Burke } \\
\qquad[24] \\
\text { Golparvar et al. [70] }\end{array}$ & $\begin{array}{l}\text { Empirical study on destructive and constructive deviance behavior: Work- } \\
\text { holism Empirical study on workplace deviance: Emotional exhaustion } \\
\text { and deviant behaviors }\end{array}$ & $\begin{array}{l}\text { NA } \\
\text { Role of big five personality } \\
\text { traits (Moderator) }\end{array}$ & $\begin{array}{l}\text { Social Exchange theory, Need for } \\
\text { achievement theory, Locus of control } \\
\text { theory and social bonding theory } \\
\text { NA }\end{array}$ \\
\hline Henle [71] & Empirical study on workplace deviance: Justice & Socialization impulsive & NA \\
\hline Holtz and Harold [72] & Empirical study on workplace deviance: Interpersonal justice & $\begin{array}{l}\text { Interpersonal justice values } \\
\text { and justice orientation } \\
\text { (Moderator) }\end{array}$ & $\begin{array}{l}\text { Social exchange theory, social } \\
\text { learning theory and extant theory, } \\
\text { influential theory and effective } \\
\text { events theory }\end{array}$ \\
\hline Hussain [73] & Empirical study on workplace deviance: Psychological contract & NA & NA \\
\hline $\begin{array}{l}\text { Ishaq and Shamsher } \\
{[74]}\end{array}$ & $\begin{array}{l}\text { Empirical study on workplace deviance behavior: Psychological contract } \\
\text { breach }\end{array}$ & $\begin{array}{l}\text { Revenge attitude and Self- } \\
\text { Control (Moderating) }\end{array}$ & Psychological contract breach \\
\hline
\end{tabular}


Citation: Baharom MN, Sharfuddin MDKB, Iqbal J (2017) A Systematic Review on the Deviant Workplace Behavior. Review Pub Administration Manag 5: 231. doi:10.4172/2315-7844.1000231

Page 5 of 8

\begin{tabular}{|c|c|c|c|}
\hline $\begin{array}{l}\text { Iqbal, Baharom and } \\
\text { Khairi [75] }\end{array}$ & $\begin{array}{l}\text { Empirical study on deviance workplace behavior: Transformational } \\
\text { leadership }\end{array}$ & NA & NA \\
\hline $\begin{array}{l}\text { Iqbal, Baharom and } \\
\text { Khairi [76] }\end{array}$ & Empirical study on deviant workplace behavior: Demographic Factors & - & $\begin{array}{l}\text { Social exchange theory, Social } \\
\text { learning theory, psychological } \\
\text { breach contract theory }\end{array}$ \\
\hline Javed et al. [6] & $\begin{array}{c}\text { Empirical study on workplace deviance: Personality factor and } \\
\text { organizational factors }\end{array}$ & NA & NA \\
\hline $\begin{array}{l}\text { Judge, Scott and Ilies } \\
\text { [77] }\end{array}$ & Empirical study on workplace deviance: Emotions and work attitude & $\begin{array}{l}\text { Trait hostility } \\
\text { (Moderator) }\end{array}$ & Affective events theory \\
\hline Kanten and Ulker [18] & Empirical study on workplace deviance; & NA & NA \\
\hline Kotekar [78] & Empirical study on deviant workplace behavior: withdrawal intention & NA & NA \\
\hline Kisamore et al. [79] & Empirical study on workplace deviance: conflict and abusive workplace & $\begin{array}{l}\text { Social competencies (political } \\
\text { skill, self-monitoring, and } \\
\text { emotional intelligence) }\end{array}$ & NA \\
\hline $\begin{array}{l}\text { Kura, Shamsudin, and } \\
\text { Chauhan }[80]\end{array}$ & Empirical study on workplace deviance: Organizational formal control & $\begin{array}{l}\text { Self-regulatory efficacy } \\
\text { (Moderator) }\end{array}$ & $\begin{array}{l}\text { Stimulus response theory and social } \\
\text { cognitive theory }\end{array}$ \\
\hline Kura, et al. [81] & $\begin{array}{c}\text { Empirical study on workplace deviance: Precived injunctive, descriptive } \\
\text { and self-regulatory efficacy affect and cognitions }\end{array}$ & $\begin{array}{l}\text { Self-regulatory efficacy } \\
\text { (Moderator) }\end{array}$ & $\begin{array}{l}\text { Social learning theory and social } \\
\text { efficacy theory }\end{array}$ \\
\hline Lara et al. [82] & Empirical study on workplace deviance: effect of procedural justice & $\begin{array}{l}\text { Perceived normative conflict } \\
\quad \text { (mediating variable) }\end{array}$ & - \\
\hline $\begin{array}{l}\text { Lee and Allen [83] } \\
\text { Lim et al. [33] }\end{array}$ & $\begin{array}{l}\text { Empirical study on workplace deviance: Affect (positive and negative } \\
\text { Affect) and cognitions } \\
\text { Empirical study on workplace deviance Personality traits on workplace } \\
\text { deviance }\end{array}$ & $\begin{array}{l}\text { NA } \\
\text { NA }\end{array}$ & $\begin{array}{l}\text { NA } \\
\text { NA }\end{array}$ \\
\hline Mayer et al. [84] & Empirical study on workplace deviance: Leader Mistreatment & $\begin{array}{l}\text { Hostility (Mediator)and } \\
\text { Competence uncertainty } \\
\quad((\text { Moderator })\end{array}$ & $\begin{array}{l}\text { Social Exchange theory and } \\
\text { Uncertainty Management Theory }\end{array}$ \\
\hline $\begin{array}{l}\text { Marcus and Schuler } \\
{[85]}\end{array}$ & $\begin{array}{l}\text { Empirical study on counterproductive workplace behavior: } 24 \text { predictors } \\
\text { of GCB }\end{array}$ & NA & $\begin{array}{l}\text { Self-control theory. The General } \\
\text { theory of crime, }\end{array}$ \\
\hline $\begin{array}{l}\text { Mount, Ilies and } \\
\text { Johnson [86] }\end{array}$ & Empirical study on workplace deviance: personality traits & $\begin{array}{l}\text { Job satisfaction } \\
\text { (Mediator) }\end{array}$ & Social Exchange Theory \\
\hline Muafi [87] & $\begin{array}{l}\text { Empirical study on workplace deviance: Intent to quit, dissatisfaction and } \\
\text { company contempt }\end{array}$ & NA & $\begin{array}{l}\text { Attribution theory, accountability } \\
\text { theory and social distance theory }\end{array}$ \\
\hline Nasir and Bashir [88] & $\begin{array}{c}\text { Empirical study on workplace deviance: Job satisfaction and } \\
\text { organizational justice }\end{array}$ & NA & NA \\
\hline $\begin{array}{l}\text { Narayanan and Murphy } \\
{[89]}\end{array}$ & Review on workplace deviance behavior & Culture (Moderator) & Social Cognitive theory \\
\hline Nirankari and Seth [90] & $\begin{array}{l}\text { Framework on deviant workplace behavior: conflict, justice perception, } \\
\text { control, mental stress }\end{array}$ & NA & NA \\
\hline Novalien [9] & $\begin{array}{l}\text { Conceptual framework on deviant workplace behavior: Ethical Climate } \\
\text { and National Culture }\end{array}$ & $\begin{array}{l}\text { Workplace Spirituality and } \\
\text { Organizational } \\
\text { Commitment (Mediators) }\end{array}$ & NA \\
\hline Omer et al. & $\begin{array}{l}\text { Empirical study on deviance workplace behavior: Job stress and Job } \\
\text { satisfaction }\end{array}$ & NA & NA \\
\hline Peterson [91] & Empirical study on workplace deviance: organization's ethical climate & NA & Ethical Theory \\
\hline $\begin{array}{l}\text { Peng, Tseng and Lee } \\
\text { [92] }\end{array}$ & $\begin{array}{l}\text { Empirical study on deviance behavior: supervisor feedback environment } \\
\text { and work related stressor }\end{array}$ & NA & NA \\
\hline Pradhan [93] & $\begin{array}{l}\text { Empirical study on workplace deviance: Leadership (transformational } \\
\text { and transactional) }\end{array}$ & NA & NA \\
\hline $\begin{array}{l}\text { Pradhan and Pradhan } \\
\text { [93] }\end{array}$ & $\begin{array}{l}\text { Empirical study on deviance workplace behavior: Impact of } \\
\text { transformational leadership }\end{array}$ & $\begin{array}{l}\text { Organizational Justice } \\
\text { (Moderator) }\end{array}$ & NA \\
\hline $\begin{array}{l}\text { Radzali, Ahmad and } \\
\text { Omar [94] }\end{array}$ & $\begin{array}{l}\text { Empirical study on deviant workplace behavior; workload, job stress and } \\
\text { family to work conflict }\end{array}$ & NA & NA \\
\hline Raheem et al. & $\begin{array}{l}\text { Empirical study on deviance workplace behavior: Impact of Job } \\
\text { Characteristics }\end{array}$ & NA & NA \\
\hline Rogojan [95] & $\begin{array}{l}\text { Literature review on workplace deviance; } \\
\text { Individual, organizational and situational factors }\end{array}$ & NA & NA \\
\hline $\begin{array}{l}\text { Rotundo } \\
\text { and Xie [96] }\end{array}$ & $\begin{array}{c}\text { Empirical studies on counterproductive work } \\
\text { Behavior: study } 1 \text { investigates whether CWB in China is described } \\
\text { by similar or different behaviors as in the Western literature. Study } \\
2 \text { examines the importance that Chinese managers place on task } \\
\text { performance, OCB, and CWB. }\end{array}$ & - & - \\
\hline $\begin{array}{l}\text { Satpathy, Patnaik and } \\
\text { Mohanty [97] }\end{array}$ & Review deviant workplace behavior & NA & NA \\
\hline $\begin{array}{l}\text { Silva and Ranasinghe } \\
\text { [98] }\end{array}$ & $\begin{array}{l}\text { Empirical study on deviant workplace behavior: impact job stress, } \\
\text { workload, Role conflict and } \\
\text { role ambiguity }\end{array}$ & NA & NA \\
\hline Shazad and Mehmood & Empirical study on workplace deviance: Organizational cynicism & $\begin{array}{l}\text { Burnout(mediator) and } \\
\text { Negative affectivity }\end{array}$ & $\begin{array}{l}\text { Social exchange theory, Effort } \\
\text { reward in balance theory and equity } \\
\text { theory }\end{array}$ \\
\hline
\end{tabular}




\begin{tabular}{|c|c|c|c|}
\hline $\begin{array}{l}\text { Shaheen, Bashir, and } \\
\text { Khan [99] }\end{array}$ & $\begin{array}{l}\text { Empirical study on Organizational cronyism as an antecedent of orkplace } \\
\text { deviance }\end{array}$ & $\begin{array}{l}\text { Psychological breach of } \\
\text { contract (Mediator) }\end{array}$ & \\
\hline Shahid \& Ahmad [100] & $\begin{array}{l}\text { The empirical study of Impact of and the Deviant Workplace Behavior: } \\
\text { Organizational Learning on Organizational Corruption }\end{array}$ & $\begin{array}{l}\text { Moral disengagement } \\
\text { (Mediator) }\end{array}$ & N/A \\
\hline Sudha and Khan [101] & $\begin{array}{l}\text { Empirical study on workplace deviance: Personality and motivational } \\
\text { traits }\end{array}$ & NA & NA \\
\hline Sili et al. [102] & $\begin{array}{c}\text { Empirical study on Counterproductive Behavior and moral } \\
\text { disengagement }\end{array}$ & NA & NA \\
\hline Sunday [103] & $\begin{array}{c}\text { Empirical study on workplace deviance; Organizational Climate., } \\
\text { Organizational justice Perceived organization support, Trust in } \\
\text { organization, work stress and powerlessness }\end{array}$ & NA & NA \\
\hline Thau and Mitchell [104] & Empirical study on workplace deviance: Abusive supervision & Self-regulation impairment & $\begin{array}{l}\text { Social exchange theory, self- } \\
\text { regulation impairment theory and } \\
\text { dissonance theory }\end{array}$ \\
\hline Tziner et al. [105] & $\begin{array}{c}\text { Empirical study on constructive, innovative, Challenging and } \\
\text { interpersonal deviance behavior }\end{array}$ & NA & Leader - member exchange theory \\
\hline Tuclea et al. [106] & $\begin{array}{c}\text { Empirical study on deviant workplace behavior: investigation of } \\
\text { Demission of DWB }\end{array}$ & NA & NA \\
\hline $\begin{array}{l}\text { Vadera, Pratt andMishra } \\
{[107]}\end{array}$ & $\begin{array}{c}\text { Model on constructive workplace deviance: Intrinsic motivation, felt } \\
\text { obligation and Psycho-logical empowerment }\end{array}$ & NA & NA \\
\hline WU and Lebreton [108] & $\begin{array}{l}\text { Empirical study on Reconsidering the Dispositional Basis } \\
\text { Of Counterproductive work behavior: The Role of Aberrant Personality }\end{array}$ & $\begin{array}{l}\text { Dark Triad Narcissism, } \\
\text { Machiavellianism, } \\
\text { Psychopathy }\end{array}$ & NA \\
\hline Waseem [109] & $\begin{array}{l}\text { Empirical study on organizational and interpersonal deviance workplace } \\
\text { behaviors }\end{array}$ & Job satisfaction (Mediator) & NA \\
\hline Yen and Teng [110] & Empirical study on workplace deviance; Centralization & Procedural Justice (Moderator) & Social Exchange theory \\
\hline $\begin{array}{l}\text { Yunus, Khalid and } \\
\quad \text { Nordin [111] }\end{array}$ & Empirical study on workplace deviance: Personality Trait & NA & Gough's role- taking theory \\
\hline $\begin{array}{l}\text { Yildiz, Alpkan, Ates and } \\
\text { Sezen [3] }\end{array}$ & $\begin{array}{c}\text { Review on constructive deviance: Psychological ownership, Participative } \\
\text { decision making, }\end{array}$ & $\begin{array}{l}\text { Psychological ownership } \\
\text { (Mediator) }\end{array}$ & $\begin{array}{l}\text { Social exchange theory and Equity } \\
\text { theory }\end{array}$ \\
\hline Yildiz and Alpkan [4] & Theoretical model on the destructive deviant workplace behavior & Alienation (Mediator) & NA \\
\hline Zaghini et al. [112] & $\begin{array}{l}\text { A systemic review on counterproductive work behavior of Nursing } \\
\text { profession }\end{array}$ & NA & NA \\
\hline
\end{tabular}

Table 2: Summary of research published in the area of deviance workplace behavior

\section{Conclusion}

The current study has provided additional indication and evidence to the growing body of knowledge in deviant workplace behavior area. Despite of some limitations of present study, the results from the study lend support to the theoretical propositions, key objectives and answered research questions and provide Gap for future research on the area of DWB. In spite of, there have been number of studies carried out to examining the underlying antecedents and causes of deviant workplace behavior and factors contributing DWB. However, this study addressed the theoretical gap by incorporating deviant workplace behavior and transformational leadership as moderating variable between individual factors contributing deviant workplace behavior in detail. The present study also lends support to theoretical and empirical framework for the moderating role of transformational leadership on the relationship between individual and deviant workplace behavior. The outcome of this study "systemic review" also provides important practical implication to the researcher and professional to carry out further research in the DWB. In spite of the some limitations of the present study, several recommendations, directions and guidelines for future research has been drawn in this study and the practitioners and researchers can examine and clarify these testable relationships.

\section{References}

1. Appelbaum SH, Deguire KJ, Lay M (2005) The relationship of ethical climate to deviant workplace behavior. Corporate Governance. Int J Bus Soc 5: 43-55.

2. Appelbaum SH, Laconi GD, Matousek A (2007) Positive and negative deviant workplace behaviors: Causes, impacts, and solutions. Corporate Governance. Int J Bus Soc 7: 586-598.

3. Yildiz B, Alpkan L, Ates H, Sezen B (2015) Determinants of constructive deviance: The mediator role of psychological ownership. Intl Bus Res 8: 107
4. Yıldıza B, Alpkan L (2015) A theoretical model on the proposed predictors of destructive deviant workplace behaviors and the mediator role of alienation. Procedia Soc Behav Sci 210: 330-338.

5. Fox S, Spector PE, Miles D (2001) Counterproductive work behavior (CWB) in response to job stressors and organizational justice: Some mediator and moderator tests for autonomy and emotions. J Vocational Behav 59: 291-309.

6. Javed R, Amjad M, UI-Ummi LUY, Bukhari R (2014) Investigating factors affecting employee workplace deviant behavior. Int J Innov Appl Stud 9: 10731078.

7. Punia BK, Rana H (2013) Correlates, antecedents and implications of deviant workplace behavior: A review. GNA J Manage Tech 8: 98-104.

8. Bashir S, Nasir M, Qayyum S, Bashir A (2012) Dimensionality of counterproductive work behaviors in public sector organizations of Pakistan. Public Org Rev 12: 357-366.

9. Novalien CL (2017) The antecedents of deviant workplace behaviors on the employees of regional apparatus organization (odp) in maluku province. Indonesia RJOAS 6.

10. Vardi $Y$, Wiener $Y$ (1996) Misbehavior in organizations: A motivational framework. Organ Sci 7: 151-165.

11. Robinson SL, Greenberg J (1998) Employees behaving badly: Dimensions, determinants and dilemmas in the study of workplace deviance. J Organ Behav.

12. Robinson SL, Bennett RJ (1995) A typology of deviant workplace behaviors: A multidimensional scaling study. Acad J Manage, 38: 555-572.

13. Mangione TW, Quinn RP (1975) Job satisfaction, counterproductive behavior and drug use at work. J Appl Psychol 60: 114-116.

14. Harris LC, Ogbonna E (2002) Exploring service sabotage the antecedents, types and consequences of frontline, deviant, antiservice behaviors. J Serv Res 4: 163-183.

15. Griffin RW, Lopez YP (2005) Bad behaviour in organizations: A review and typology for future research. J Manage 31: 988-1005. 
16. Robinson SL, Morrison EW (1995) Psychological contracts and OCB: The effect of unfulfilled obligations on civic virtue Behavior. J Organ Behav 16: 289298.

17. Spector PE, Fox S, Penney LM, Bruursema K, Goh A, et al. (2006) The dimensionality of counterproductivity: Are all counterproductive Behaviors created equal? J Vocational Behav 68: 446-460.

18. Kanten P, Er Ülker F (2013) The effect of organizational climate on counterproductive behaviors: An empirical study on the employees of manufacturing enterprises. Macro theme Rev 2: 144-161.

19. Lim VK (2002) The IT way of loafing on the job: Cyberloafing, neutralizing and organizational justice. J Organ Behav 23: 675-694.

20. Anjum MA, Parvez A (2013) Counterproductive behavior at work: A comparison of blue collar and white collar workers. Pak J Commerce Soc Sci 7: 417-434.

21. Spector PE, Fox S (2005) The stressor-emotion model of counterproductive work behavior. pp. 151-174

22. Brown $P$ (2008) The body and society: Men, women, and sexual renunciation in early Christianity: Columbia University Press, USA

23. Alias M, Mohd Rasdi R, Ismail M, Abu Samah B (2013) Predictors of workplace deviant behavior: HRD agenda for Malaysian support personnel. Eur J Training Dev 37: 161-182.

24. Galperin BL, Burke RJ (2006) Uncovering the relationship between workaholism and workplace destructive and constructive deviance: An exploratory study. In J Hum Resour Manage 17: 331-347.

25. Appelbaum SH, Semerjian G, Mohan K (2012) Workplace bullying: consequences, causes and controls (part one). Ind Commercial Training 44 203-210.

26. Bolton L, Grawitch MJ (2011) When good employees go bad: How organizations may be facilitating workplace deviance. Good Company 5: 1-2.

27. Buss D (1993) Ways to curtail employee theft. Nation's Business 81: 36-37.

28. Chappell D, Di Martino V (2006) Violence at work (2nd edn). Int Labour Organ Geneva, Switzerland.

29. Coffin B (2003) Breaking the silence on white collar crime. Risk Manage 50 8-9.

30. Cortina LM, Magley VJ, Williams JH, Langhout RD (2001) Incivility in the workplace: Incidence and impact. J Occup Health Psychol 6: 64-80.

31. Goh A (2006) An attributional analysis of counterproductive work behaviour (CWB) in response to occupational stress. University of South Florida, USA.

32. Harper D (1990) Spotlight abuse-save profits. Ind D 79: 47-51.

33. Lim C Li, Teh JC, Benjamin FC (2016) Preliminary study of the effects of personality traits on workplace deviance in the voluntary sector. Int Rev Manage Marketing 6: 6-10.

34. Nguyen L (2013) Canadian economy loses $\$ 16.6 \mathrm{~B}$ annually due to absenteeism: Conference Board, The Star.

35. Robinson SL, O'Leary-Kelly AM (1998) Monkey see, monkey do: The influence of work groups on the antisocial behavior of employees. J Acad Manage 41 658-672.

36. Bensimon HF (1994) Crisis and disaster management: Violations in the workplace. Training Dev 28: 27-32.

37. Taylor $J$ (2007) The Impact of public service motives on work outcomes in Australia: A comparative multi-dimensional analysis. Public Admin 85: 931-959.

38. Verton D (2000) Employers ok with e-surfing. Computerworld 34: 16

39. Adejoh MA, Adejoh LL (2013) Handling negative deviant behavior of front-line employees in service organizations. Int J Cur Res Rev 5: 23-30.

40. Agboola AA, Salawu RO (2011) Managing deviant behavior and resistance to change. Int J Bus Manage 6: 235-242.

41. Ahmad A, Omar Z (2013) Abusive supervision and deviant workplace behavior: The mediating role of work family conflict. J Hum Resour Adult Learn 9: 124130

42. Ahmed W, Kiyani AA, Hashmi SH (2013) Study on organizational cynicism, organizational injustice and breach of psychological contract as the determinants of deviant work Behavior. Actual Probl Econ 2: 145-154.
43. Rahim AR, Shabudin A, Nasurdin MA (2012) Effects of job characteristics on counterproductive work behavior among production employees: Malaysian Experience. Int J Bus Dev Stud 4: 123-145.

44. Aksu A (2016) Organizational deviance and multi-factor leadership. Educ Res Rev 11: 589-597.

45. Alias M, Rasdi MR, Abu Said AM (2012) The impact of negative affectivity, job satisfaction and interpersonal justice on workplace deviance in the private organizations. Pertanika J Soc Sci Hum 20: 829-846.

46. Ambrose ML, Schminke M, Mayer DM (2013) Trickle-down effects of superviso perceptions of interactional justice: A moderated mediation approach. J Appl Psychol 98: 678-689.

47. Bagchi A, Bandyopadhyay S (2016) Workplace deviance and recession. BE J Theor Econ 16: 47-81.

48. Bahri MRZ, Langrudi MS, Hosseinian S (2013) Relationship of work environment variables and job satisfaction of employees with counterproductive work behaviors: A study of non-governmental non-benefit Islamic Azad University employees in West Mazandaran. J W Appl Sci 21: 1812-1815.

49. Bodankin M, Tziner A (2009) Constructive deviance, destructive deviance and personality: How do they interrelate. Amfiteatru J Econ 11: 549-564.

50. Bolin A, Heatherly L (2001) Predictors of employee deviance: The relationship between bad attitudes and bad behavior. J Bus Psychol 15: 405-418.

51. Bowling NA, Eschleman KJ (2010) Employee personality as a moderator of the relationships between work stressors and counterproductive work behavior. $J$ Occup Health Psychol 15: 91-103.

52. Chen CC, Chen MYC, Liu YC (2013) Negative affectivity and workplace deviance: The moderating role of ethical climate. Int $\mathrm{J}$ Hum Resour Manage 24: $2894-2910$

53. Chen LL, Fahb BCY, Jin TC (2016) Perceived organizational support and workplace deviance in the voluntary sector. Procedia Econ Financ 35: 468-475.

54. Chirasha V, Mahapa M (2012) An analysis of the causes and impact of devian behavior in the workplace. The case of secretaries in state universities. $J$ Emerg Trends Econ Manage Sci 3: 415-421.

55. Chullen CL, Dunford BB, Angermeier I, Boss RW, Boss AD (2010) Minimizing deviant behavior in healthcare organizations: The effects of supportive leadership and job design/practitioner application. J Healthcare Manage 55 381-397.

56. Chung YW, Moon HK (2011) The moderating effects of collectivistic orientation on psychological ownership and constructive deviant behavior. Int $\mathrm{J}$ Bus Manage 6: 65-77.

57. Colbert AE, Mount MK, Harter JK, Witt LA, Barrick MR (2004) Interactive effects of personality and perceptions of the work situation on workplace deviance. $J$ Appl Psychol 89: 599-609.

58. Dagher G, Junaid N (2011) 24-employee engagement and constructive devian behavior at the workplace: An empirical investigation. Paper presented at the 2011 Annual Conference IBAM 19, 13-15 October, Orlando, Florida.

59. De Lara PZM, Tacoronte DV, Ting-Ding JM (2007) Procedural justice and workplace deviance: The mediating role of perceived normative conflict in work groups. Decisions based on the knowledge and the social role of the company. Annual congress of Spanish Association of Management and Economy of the Company (AEDEM). 28: 381-393

60. Diefendorff JM, Mehta K (2007) The relations of motivational traits with workplace deviance. J Appl Psychol, 92: 967-977.

61. Demir M (2011) Effects of organizational justice, trust and commitment on employees' deviant behavior. Anatolia 22: 204-221.

62. Fagbohungbe BO, Akinbode GA, Ayodeji F (2012) Organizational determinants of workplace deviant behaviors: An empirical analysis in Nigeria. Int $\mathrm{J}$ Bus Manage 7: 207-221

63. Farasat E, Ziaaddini M (2013) Perceived organizational support and deviant behavior. J Basic Appl Sci Res 3: 517-528.

64. Fatima A, Atif QM, Saqib A, Haider A (2012) A Path model examining the relations among organizational injustice, counterproductive work behavior and job satisfaction. Int J Innov Manage Tech 3: 696-701.

65. Farhadi H, Omar F, Nasir R, Zarnaghash M, Salehi M (2015) The Role of 
demographic factors on workplace deviant behavior. J Sci Humanities 2: 032039

66. Fida R, Tramontano C, Paciello M, Kangasniemi M, Sili A, et al. (2015) Nurse moral disengagement. Nurs Ethics 23: 547-564.

67. Ferris DL, Brown DJ, Heller D (2009) Organizational supports and organizational deviance: The mediating role of organization-based self-esteem. Organ Behav Hum Dec 108: 279-286.

68. Ferris DL, Spence JR, Brown DJ, Heller D (2012) Interpersonal injustice and workplace deviance, the role of esteem threat. J Manage 38: 1788-1811.

69. Flaherty S, Moss SA (2007) The impact of personality and team context on the relationship between workplace injustice and counterproductive work behavior. J Appl Soc Psychol 37: 2549-2575.

70. Golparvar M, Dehghan S, Mehdad A (2014) Relationship between emotional exhaustion and deviant behaviours: Moderating role of big five personality traits international. J Sci Res Knowl 2: 285-296.

71. Henle CA (2005) Predicting workplace deviance from the interaction between organizational justice and personality. J Managerial Issues 17: 247-263.

72. Holtz BC, Harold CM (2013) Interpersonal justice and deviance the moderating effects of interpersonal justice values and justice orientation. J Manage 39 : 339-365.

73. Hussain MA (2013) Effect of breach of psychological contract on workplace deviant behavior.

74. Ishaq HM, Shamsher Q (2016) Effect of breach of psychological contracts on workplace deviant behaviors with the moderating role of revenge attitude and self-control. Pak J Commer Soc Sci 10: 69-83.

75. Iqbal J, Baharo MN, Khair MD (2017) Impact of transformational leadership on deviant workplace behavior in Pakistani public organizations. Am Res J 6: 49-61.

76. Iqbal J, Baharom MN, Khairi MD (2017) Impact of demographic factors on deviant workplace behavior in the Pakistani public organizations. Int J Manage Sci Bus Res 6.

77. Judge TA, Scott BA, llies R (2006) Hostility, job attitudes, and workplace deviance: Test of a multilevel model. J Appl Psychol 91: 126-138.

78. Kotekara V (2017) Study of deviant workplace behavior and withdrawa intentions in education sector. Int Res J Arts Educ 4: 67-72.

79. Jennifer LK, Jawahar MI, Eric WL, Tagonei LM, Thomas S (2010) Conflict and abusive workplace behaviors. The moderating effects of social competencies. Career Dev Int 15: 583-600.

80. Kura KM, Shamsudin FM, Chauhan A (2013a) Moderating effect of selfregulatory efficacy on the relationship between organizational formal controls and workplace deviance: A proposed framework. Int J Acad Res Bus Soc Sci 3: $15-26$.

81. Kura KM, Shamsudin FM, Chauhan A (2013b) Modeling the influence of group norms and self-regulatory efficacy on workplace deviant behavior. Asian Soc Sci 9: 113-122.

82. Pablo ZM, Domingo TV (2007) Investigating the effects of procedural justice on workplace deviance. Do employees' perceptions of conflicting guidance call the tune? Int J Manpower 28: 715-729.

83. Lee K, Allen NJ (2002) Organizational citizenship behavior and workplace deviance: The role of affect and cognitions. J Appl Psychol 87: 131-142.

84. Mayer DM, Thau S, Workman KM, Van Dijke M, De Cremer D (2012) Leader mistreatment, employee hostility, and deviant behaviors: Integrating selfuncertainty and thwarted needs perspectives on deviance. Organ Behave Hum Decis Processes 117: 24-40.

85. Marcus B, Schuler H (2004) Antecedents of counterproductive behavior at work: a general perspective. J Appl Psychol 89: 647-660.

86. Mount M, llies R, Johnson E (2006) Relationship of personality traits and counterproductive work Behaviors: The mediating effects of job satisfaction. Pers Psychol 59: 591-622.

87. Muafi J (2011) Causes and consequences deviant workplace behavior. Int $J$ Innov Manage Tec, 2: 123-126.

88. Nasir M, Bashir A (2012) Examining workplace deviance in public sector organizations of Pakistan. Int J Soc Econ 39: 240-253.
89. Narayanan K, Murphy SE (2017) Conceptual framework on workplace deviance behavior: A Rev J Hum Values 23: 218-233.

90. Nirankari S, Seth $N$ (2015) Work deviance effects on job performance and health. Int J Adv Nutr Health Sci 3: 132-136.

91. Peterson DK (2002) Deviant workplace behavior and the organization's ethical climate. J Bus Psychol 17: 47-61.

92. Peng JC, Tseng MM, Lee YJ (2011) Relationships among supervisor feedback environment, work-related stressors, and employee deviance. J Nurs Res 19 13-24.

93. Pradhan S, Pradhan KR (2014) Transformational leadership and deviant workplace behaviors: The moderating role of organizational justice. Proceedings of the first Asia Pacific Conference on Global Business, economics, finance and social sciences (AP14SINGAPORE Conference) Singapore.

94. Radzali MF, Ahmad A, Omar Z (2013) Workload, job stress, family-to-work conflict and deviant workplace behavior. Int J Academic Res Bus Soc Sci 3 : 109-115.

95. Rogojan PT (2009) Deviant workplace behavior in organizations (Doctora dissertation). University of Vienna, Austria.

96. Rotundo M, Xie JL (2008) Understanding the domain of counterproductive work behaviour in China. Int J Hum Resour Manage 19: 856-877.

97. Satpathy I, Patnaik BCM, Mohanty S (2016) Dynamics of deviant workplace behavior-a literature review. Int J Humanities Soc Stud 4: 1-4.

98. Michelle SHSV, Ranasinghe RMID (2016) The Impact of job stress on devian workplace behavior: A study of operational level employees of comfort apparel solutions company in Sri Lanka. Int J Hum Resour Stud 7: 74-85.

99. Shaheen S, Bashir S, Khan AK (2017) Examining organizational cronyism as an antecedent of workplace deviance in public sector organizations. Public Personnel Manage 46: 308-323.

100. Shahid B, Ahmad I (2016) The impact of organizational learning on organizational corruption and the deviant workplace behavior: The case study of public sector organizations in Pakistan. NUML Int J Bus Manage 11: 50-67.

101. Sudha KS, Khan W (2013) Personality and motivational traits as correlates of workplace deviance among public and private sector employees. J Psychol 4: 25-32.

102. Sili A, Fida R, Zaghini F, Tramontano C, Paciello M (2014) Counterproductive behaviors and moral disengagement of nurses as potential consequences of stress-related work: Validity and reliability of measurement scales. Med Lav 105: 382-394

103. Sunday AJ (2014) The causes and impart of deviant behavior in the work place. Ame J Soc Sci Arts Lit 1: 1-11.

104. Thau S, Mitchell MS (2010) Self-gain or self-regulation impairment? Tests of competing explanations of the supervisor abuse and employee deviance relationship through perceptions of distributive justice. J Appl Psychol 95: 1009-1031.

105.Tziner A, Fein EC, Sharoni G, Bar-Hen P, Nord T (2010) Constructive deviance, leader-member exchange, and confidence in appraisal: How do they interrelate, if at all? Rev Psicol Trab Organ 26: 95-100.

106. Tuclea EC, Vranceanu MD, Filip A (2015) Dimensions of deviant workplace behavior in small and medium sized enterprises. Rev Int Comp Manage 16: 23-38.

107. Vadera AK, Pratt MG, Mishra P (2013) Constructive deviance in organizations: Integrating and moving forward. J Manage 39: 1221-1276.

108.WU J, Lebreton JM (2011) Reconsidering the dispositional basis of counterproductive work behavior: The role of aberrant personality. Pers Psychol 64: 593-626.

109. Waseem M (2016) Deviant workplace behaviors in organizations in Pakistan. The Lahore J Bus 4: 93-104.

110. Yen $\mathrm{CH}$, Teng HY (2013) The effect of centralization on organizational citizenship behavior and deviant workplace behavior in the hospitality industry. Tourism Manage 36: 401-410.

111. Yunus OM, Khalid K, Nordin M (2012) A personality trait and workplace deviant behaviors. Hum Resour Manage 47: 8678-8683.

112. Zaghini F, Fida R, Caruso R, Kangasniemi M, Sili A (2016) What is behind counterproductive work behaviors in the nursing profession? A systematic review. J Clin Res Bioeth 7: 1-7. 